\title{
THICKENING OF SPINE LIGAMENTUM FLAVUM AND FACET TROPISM
}

\author{
ESPESSAMENTO DO LIGAMENTO AMARELO DA COLUNA VERTEBRAL \\ E TROPISMO FACETÁRIO
}

\author{
ENGROSAMIENTO DEL LIGAMENTO AMARILLO DE LA COLUMNA VERTEBRAL \\ Y TROPISMO FACETARIO \\ Paulo Roberto Appolonio ${ }^{1}$, Thiago Mattar ${ }^{1}$, Alexandre Barros Costa ${ }^{1}$, Edgar Santiago Valesin Filho', Luciano Miller Reis Rodrigues ${ }^{1}$
}

\begin{abstract}
Objective: This study investigated the thickening of the ligamentum flavum (LF) and its correlation with facet tropism and its severity at different levels of the spine. Method: This retrospective study was performed with patients with chronic back pain consecutively admitted to a specialized spinal surgery service between January 2012 and January 2013. All patients underwent magnetic resonance imaging (MRI) to measure the thickness of the LF and facet tropism severity (severe, moderate or absent) according to the spine levels (L3 - L4, $L 4$ - L5, L5-S1). The association between the thickness of LF and facet tropism was analyzed. Results: During the study period, 98 consecutive patients were enrolled with a mean age of 53.6 years, most women (59.2\%). There was no significant difference between the thicknesses of the ligament and the presence of tropism in different spinal levels $(p>0.05)$. The thickness of LF was significantly associated with the severity of tropism only in L5-S1 level $(p<0.03)$. Conclusions: Our results show that there is a positive relationship between severe facet tropism and increased thickness of the LF in the L5-S1 level.
\end{abstract}

Keywords: Spine; Ligamentum flavum; Intervertebral disc; Intervertebral disc degeneration.

\section{RESUMO}

Objetivo: Este estudo investigou se o espessamento do ligamento amarelo (LA) está correlacionado com a presença de tropismo facetário e sua gravidade nos diferentes níveis da coluna vertebral. Método: Este estudo retrospectivo foi realizado com pacientes com dor lombar crônica, consecutivamente admitidos em serviço especializado em cirurgia da coluna vertebral entre janeiro de 2012 e janeiro de 2013 . Todos foram submetidos a exames de ressonância magnética (RM) para mensurar a espessura do LA e a gravidade do tropismo facetário (grave, moderada e ausente) conforme os níveis da coluna (L3-L4, L4-L5, L5-S1). Foi analisada a associação entre a espessura do LA e o tropismo. Resultados: No período do estudo, foram admitidos 98 pacientes, com média de idade de 53,6 anos, maioria de mulheres (59,2\%). Não foi verificada diferença significativa entre as espessuras dos ligamentos e a presença de tropismo nos diferentes níveis $(p>0,05)$. A espessura do LA associou-se significativamente à gravidade do tropismo apenas no nível L5-S1 ( $p<0,03$ ). Conclusões: Os resultados do nosso estudo mostram que existe uma relação positiva entre tropismo facetário grave e aumento da espessura do LA no nível L5-S1.

Descritores: Coluna vertebral; Ligamento amarelo; Disco intervertebral; Degeneração do disco intervertebral.

\section{RESUMEN}

Objetivo: Este estudio investigó si el engrosamiento del ligamento amarillo (LA) se correlaciona con la presencia de tropismo facetario y su gravedad en diferentes niveles de la columna vertebral. Método: Estudio retrospectivo se realizó con pacientes con dolor de espalda crónico, ingresados consecutivamente al servicio especializado en cirugía de columna entre enero de 2012 y enero de 2013. Todos los pacientes fueron sometidos a una resonancia magnética (MRI) para medir el espesor del LA y la gravedad de tropismo facetario (grave, moderada o ausente) según los diversos niveles (L3-L4, L4-L5 y L5-S1). Se analizó la asociación entre el espesor del LA y el tropismo. Resultados: Durante el período de estudio, 98 pacientes fueron incluidos, con edad promedio de 53,6 años, siendo la mayoría mujeres (59,2\%). No hubo diferencia significativa entre los espesores de los ligamentos y la presencia de tropismo en niveles diferentes ( $p>0,05)$. El espesor del LA se asoció significativamente con la gravedad del tropismo solo en el nivel L5-S1 ( $<<0,03)$. Conclusiones: Los resultados de nuestro estudio muestran que existe una relación positiva entre la severidad del tropismo facetario y el aumento del espesor del LA en el nivel L5-S1.

Descriptores: Columna vertebral; Ligamento amarillo; Disco intervertebral; La degeneración del disco intervertebral.

\section{INTRODUCTION}

The ligamentum flavum (LF), also known as the ligamentum flavum due to its coloring, is a spinal structure overlying the lateral and posterior walls of the vertebral canal, and is in intimate contact with the nerve structures. Its thickening can be a cause of lumbar canal stenosis and hence low back pain due to the compression of the dural sac and/or nerve roots. The LF has an important role in the stability of vertebral column. ${ }^{1,2}$ Its elasticity, however, decreases with age, with the gradual replacement of the elastic fibers by collagen fibers, ${ }^{3,4}$ which means it is likely involved in a number of diseases of the spine. For example, the thickening of the LF associated with spinal stenosis has been studied, ${ }^{5,6}$ since it reduces the diameter of the medullary canal, compressing the dural

1. Faculdade de Medicina do ABC, Santo André, SP, Brazil.

Study conducted at the Faculdade de Medicina da Fundação do ABC. Department of Diseases of the Locomotor System, Spine Surgery Group, Santo André, SP, Brazil. Correspondence: Luciano Miller Reis Rodrigues. Rua Tucumã, 199, apto 141. São Paulo. SP, Brasil. 01455-010. luciano.miller@uol.com.br 
sac and nerve roots. This phenomenon of thickening and dimming contributes to low back pain and sciatica, even when there are no herniation or bone spurs. ${ }^{1,7}$

The causes of LF thickening are still unknown, ${ }^{8}$ but some researchers have postulated the hypothesis that micro-movements on the articular surfaces around the canal lead to decreased stability of the joint capsules, thus leading to degenerative changes, such as osteophytic reactions, thickening, and calcification of the LF. ${ }^{9}$ Research currently focuses on what other factors besides aging, could be related to the thickness of the ligamentum flavum: ${ }^{8}$ broad segmental movements in the long term and disc degeneration may be related to the hypertrophy of this ligament. ${ }^{8}$

The facet tropism is defined as the asymmetry of the angle of both of the facet joints in the lumbar and lumbosacral region. Published studies have established a positive relationship between facet tropism and disc degeneration, disc herniation, and vertebral spondylolysis, and it has already been shown that osteoarthritis in aging may interfere with facet tropism and with the thickening of the ligamentum flavum at different levels. ${ }^{10,11}$ However, the linking of facet tropism with thickening of the ligamentum flavum has not been studied in patients without osteoarthritis.

This study aims to investigate the hypothesis that the thickness of the ligamentum flavum is correlated with the degree of facet tropism at different levels of the spine.

\section{METHODS}

\section{Study design and population}

This retrospective observational study was based on the records and magnetic resonance imaging (MRI) studies of the lumbar spine of all consecutive patients undergoing this examination in the Spine Surgery Outpatient Clinic at the Faculdade de Medicina do ABC from January 2012 to January 2013 with chronic low back pain.

Patients with chronic low back pain with symptoms for at least three months were included. Patients who had severe scoliosis, formation defects, infectious or tumoral processes, and patients who had undergone previous spinal surgery were excluded.

\section{Measuring the facet angle and degree}

Axial T1-weighted MR images were used. The angulation of the facet joints was measured at the levels of L3-L4, L4-L5 and L5-S1 bilaterally.

The angles of facet tropism were measured by two members of the Spine Group (PRA and TM) at the levels studied, totaling three levels (L3-L4, L4-L5, and L5-S1). The evaluators worked by consensus to record a final value for each case. The angles of the facet joints were measured using $\mathrm{T} 1$ axial slices on the MRI, using 1.5 Tesla, with 5-mm slices. The reference lines were the posterior aspect of the vertebral body (perpendicular to the sagittal plane) and a line tangential to the superior facet of the articular process. The degree of tropism (asymmetry) was classified according to the method described by Vanharanta et al., ${ }^{12}$ who defined tropism as absent with differences smaller than $7^{\circ}$, moderate with a difference between $7^{\circ}$ and $15^{\circ}$, and severe tropism with more than $15^{\circ}$.

The thickness of the ligamentum flavum was measured on the T1-weighted axial slices at the height of the facet joint in the middle portion of the ligament, bilaterally, in millimeters.

All measurements were performed by the same evaluators (PRA and TM) on three different occasions, and the mean values were adopted. In cases of different LF thicknesses at the same level, the higher value thickness was used.

\section{Statistical analysis}

In this study, the qualitative characteristics of the patients were described using absolute and relative frequencies, and the quantitative characteristics, such as age, as means and standard deviations. The thickness of the LF was described according to the presence of tropism using summary measurements (mean, standard deviation, median, minimum, and maximum), and compared according to the presence of tropism using the Student's t-test, and according to the severity of the tropism using analysis of variance (ANOVA) with repeated measures, ${ }^{13,14}$ followed by multiple comparisons to identify between which severity levels there are significant differences in the thickening of the LF.

Analyses were performed using the Statistical Package for Social Sciences (SPSS), version 17.0, and a significance level of $5 \%$ $(<=0.05)$ was assumed for all tests.

\section{RESULTS}

During the study period, 98 individuals (56 of them, or $59.2 \%$, women) aged 15-87 years (mean 53.6 years; standard deviation, $\mathrm{SD}=13.6$ years) were included. Although we did not expect to find thickening of the ligamentum flavum in young patients, these patients were included in the analysis of the study as a control group for the values found. Table 1 shows the measurements of the LF thickness and the presence and severity of the facet tropism according to the level of the spine.

Table 2 demonstrates the relationship between the thickening of the LF and the presence of tropism, and shows that there is no significant difference between the thicknesses of the ligaments and the presence of tropism at the different levels $(p>0.05)$.

We sought to determine whether the LF thickness at different levels would have some relationship to the severity of tropism in analysis of variance (ANOVA) (Table 3). This association only appears to be significant at the L5-S1 level. As can also be seen in Table 4, patients with severe tropism at this level have greater ligament thickness than patients with tropism that is moderate or absent ( $p=0.012$ and $p=0.023$ respectively). There was no statistical significance $(p>0.999)$ for patients with tropism that was absent to moderate.

Table 1. Means and standard deviations (SD) of the thickness of the ligamentum flavum and the classification of facet tropism according to the level of the spine.

\begin{tabular}{c|c}
\hline Variable & Mean (SD) \\
\hline Thickness L3/L4 & $0.262(0.081)$ \\
\hline Thickness L4/L5 & $0.345(0.104)$ \\
\hline Thickness L5/S1 & $0.273(0.079)$ \\
\hline Tropism L3/L4 & $N(\%)$ \\
\hline Absent & $56(57.2)$ \\
\hline Moderate & $31(31.6)$ \\
\hline Severe & $11(11.2)$ \\
\hline
\end{tabular}

\section{Tropism L4/L5}

\begin{tabular}{c|c}
\hline Absent & $50(51.0)$ \\
\hline Moderate & $36(36.7)$ \\
\hline Severe & $12(12.3)$ \\
\hline \multicolumn{2}{c}{ Tropism L5/S1 } \\
\hline Absent & $45(45.9)$ \\
\hline Moderate & $38(38.8)$ \\
\hline Severe & $15(15.3)$ \\
\hline
\end{tabular}


Table 2. Mean and standard deviation (SD) of the thickening of the ligamentum flavum according to the levels and according to the presence of facet tropism and Student's t-test results.

\begin{tabular}{c|c|c|c|c|c|c|c|c|}
\hline Variable & Tropism & Mean & SD & Median & Minimum & Maximum & $\mathbf{N}$ & $\mathbf{p}$ \\
\hline \multirow{2}{*}{ Thickness L3/L4 } & Absent & 0.262 & 0.078 & 0.28 & 0.11 & 0.54 & 56 \\
\cline { 2 - 9 } & Present & 0.263 & 0.085 & 0.26 & 0.12 & 0.44 & 42 \\
\hline \multirow{2}{*}{ Thickness L4/L5 } & Absent & 0.340 & 0.103 & 0.33 & 0.18 & 0.58 & 50 \\
\cline { 2 - 9 } & Present & 0.351 & 0.106 & 0.36 & 0.17 & 0.57 & 48 & 0.185 \\
\hline \multirow{2}{*}{ Thickness L5/S1 } & Absent & 0.262 & 0.072 & 0.26 & 0.14 & 0.44 & 45 \\
\cline { 2 - 9 } & Present & 0.283 & 0.085 & 0.28 & 0.14 & 0.54 & 53 \\
\hline
\end{tabular}

Table 3. Analysis of variance (ANOVA) of the mean and standard deviation (SD) of the thickening of the ligamentum flavum according to the severity of facet tropism.

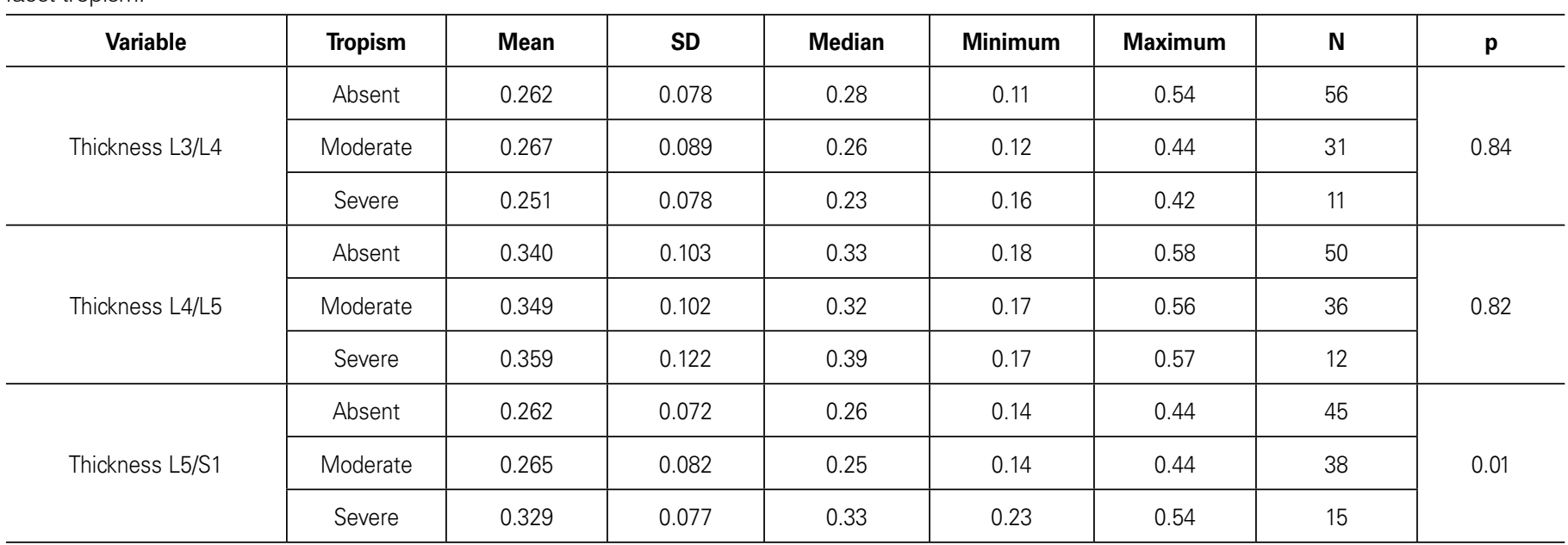

Table 4. Results of multiple comparisons considering the ligament thickness at $L 5 / S 1$ as a dependent variable among the levels of facet tropism severity.

\begin{tabular}{c|c|c|c|c|c}
\hline \multirow{2}{*}{ Comparison } & \multirow{2}{*}{$\begin{array}{c}\text { Mean } \\
\text { difference }\end{array}$} & $\begin{array}{c}\text { Standard } \\
\text { error }\end{array}$ & $\mathbf{p}$ & \multicolumn{2}{|c}{ Cl (95\%) } \\
\cline { 5 - 6 } & -0.003 & 0.017 & $>0.999$ & -0.044 & 0.038 \\
\hline Absent-Moderate & -0.067 & 0.023 & 0.012 & -0.123 & -0.011 \\
\hline Absent-Severe & -0.067 Sior & Superior \\
\hline Moderate-Severe & -0.064 & 0.023 & 0.023 & -0.121 & -0.007 \\
\hline
\end{tabular}

\section{DISCUSSION}

With the aging of the population, the number of cases of spinal canal stenosis due to the natural spinal degeneration process has increased. In parallel with this, surgical techniques for decompression of the spinal canal have made advancements, but the causes of this canal stenosis still need clarification, especially in relation to the hypertrophy of the ligamentum flavum.

To evaluate the hypothesis that there is a relationship between the thickness of the LF and the facet tropism, the presence of tropism and its classification by severity was assessed by MRI, and the LF thickness was measured at different levels of the spine. It was found, however, that only at the L5-S1 level there is a positive relationship between the presence of severe facet tropism and increased thickness of the LF. These results suggest that severe facet tropism at the L5-S1 level can be the cause of micro-movements and consequent instability, causing a thickening of the LF in an attempt to stabilize the spine functional unit.
A recently published study by Liu et al. ${ }^{11}$ already demonstrated a positive association between the degree of asymmetric facet arthrosis, facet tropism, and the thickness of the ligamentum flavum in the lower lumbar segments (L4-L5 and L5-S1), confirming the hypothesis that abnormal movements in the lumbar segments lead to hypertrophy of the LF.

In our study, there was no relationship between facet tropism and an increased thickness of the ligamentum flavum at L3-L4 and L4-L5, perhaps due to the lower mobility of these two levels compared to the L5-S1 level. Another possible explanation is that we evaluated patients without a specific diagnosis of facet arthrosis, that is, patients were not divided into different subgroups according to the severity of facet arthrosis present, as proposed by Liu et al. ${ }^{11}$

In addition to mechanical factors, biochemical factors also appear to be involved in the hypertrophy of the LF. Cytokines released by the facet osteoarthritis, such as TGF-beta, IL-1, 6, 8, 15, TNF-alpha, and COX-2 are associated with the hypertrophy of the LF.15-18

The decrease of the height of the intervertebral disc has been associated with an increase of the localized thickness of the ligamentum flavum, but this relationship has not always been positive. ${ }^{8}$ Structural changes in the ligament associated with the decreased disc height seem to enhance this thickening in these cases.

Our study has limitations, such as the fact that it is retrospective and observational, and contains a limited number of patients. In addition, measurements were made based on magnetic resonance images, that is, two-dimensional images that fail to demonstrate the complex three-dimensional morphology of the facet joints. The thickness of the ligamentum flavum considered for the analyses was the largest one found when there were different measurements 
at the same level, so we did not evaluate the difference between individual measurements.

It was also not possible to obtain data from MRI studies of individuals without back pain to compose a control group. Since the normal parameters of LF thickness are not available in the literature, the conclusions about the association with other measures remain limited.

Currently, all therapies have been directed to the intervertebral disc, mainly due to the different mechanisms of low back and radicular pain. ${ }^{19,20}$ With the aging of the population, it is necessary to develop more studies concerning the etiology of the spinal canal stenosis, not only to understand what is causing the reduction of the spinal canal, but the origin of this reduction, that is, what are the anatomical factors that increase the hypertrophy of the ligament. In this particular study, we studied facet tropism.

\section{CONCLUSION}

The results of our study show that there is a positive relationship between severe facet tropism and an increased thickness of the LF at the L5-S1 level.

All authors declare no potential conflict of interest concerning this article.

\section{REFERENCES}

1. Safak AA, Is M, Sevinc O, Barut C, Eryoruk N, Erdogmus B, Dosoglu M. The thickness of the ligamentum flavum in relation to age and gender. Clin Anat. 2010;23(1):79-83.

2. Abbas J, Hamoud K, Masharawi YM, May H, Hay O, Medlej B, et al. Ligamentum flavum thickness in normal and stenotic lumbar spines. Spine (Phila Pa 1976). 2010:35(12):1225-30.

3. Kosaka H, Sairyo K, Biyani A, Leaman D, Yeasting R, Higashino K, et al. Pathomechanism of loss of elasticity and hypertrophy of lumbar ligamentum flavum in elderly patients with lumbar spinal canal stenosis. Spine (Phila Pa 1976). 2007:32(25):2805-11.

4. Olszewski AD, Yaszemski MJ, White AA 3rd. The anatomy of the human lumbar ligamentum flavum. New observations and their surgical importance. Spine (Phila Pa 1976). 1996:21(20):2307-12.

5. Yoshida M, Shima K, Taniguchi Y, Tamaki T, Tanaka T. Hypertrophied ligamentum flavum in lumbar spinal canal stenosis. Pathogenesis and morphologic and immunohistochemical observation. Spine (Phila Pa 1976). 1992;17(11):1353-60.

6. Grenier N, Kressel HY, Schiebler ML, Grossman RI, Dalinka MK. Normal and degenerative posterior spinal structures: MR imaging. Radiology. 1987;165(2):517-25.

7. Park JB, Chang H, Lee JK. Quantitative analysis of transforming growth factor-beta 1 in ligamentum flavum of lumbar spinal stenosis and disc herniation. Spine (Phila Pa 1976). 2001;26(21):E492-5.

8. Altinkaya N, Yildirim T, Demir S, Alkan O, Sarica FB. Factors associated with the thickness of the ligamentum flavum: is ligamentum flavum thickening due to hypertrophy or buckling? Spine (Phila Pa 1976). 2011:36(16):E1093-7.

9. Jane JA Sr, Jane JA Jr, Helm GA, Kallmes DF, Shaffrey Cl, Chadduck JB, et al. Acquired lumbar spinal stenosis. Clin Neurosurg. 1996;43:275-99.

10. Chadha M, Sharma G, Arora SS, Kochar V. Association of facet tropism with lumbar disc herniation. Eur Spine J. 2013;22(5):1045-52.

11. Liu HX, Shen Y, Shang P, MaYX, Cheng XJ, Xu HZ. Asymmetric facet joint osteoarthritis and its relationships to facet orientation, facet tropism and ligamentum flavum thickening. J Spinal Disord Tech. 2013 Nov 8. [Epub ahead of print]

12. Vanharanta H, Floyd T, Ohnmeiss DD, Hochschuler SH, Guyer RD. The relationship of facet tropism to degenerative disc disease. Spine (Phila Pa 1976). 1993:18(8):1000-5

13. Neter J, Kutner MH, Nachtsheim CJ, Wasserman W. applied linear statistical models. 4th ed. Ilinois: Richard D. Irwing; 1996.

14. Kirkwood BR, Sterne JAC. Essential medical statistics. 2nd. ed. Blackwell Science: Massachusetts; 2006.

15. Igarashi A, Kikuchi S, Konno S. Correlation between inflammatory cytokines released from the lumbar facet joint tissue and symptoms in degenerative lumbar spinal disorders. J Orthop Sci. 2007:12(2):154-60.

16. Igarashi A, Kikuchi S, Konno S, Olmarker K. Inflammatory cytokines released from the facet joint tissue in degenerative lumbar spinal disorders. Spine (Phila Pa 1976). 2004;29(19):2091-5

17. Park JB, Chang H, Lee JK. Quantitative analysis of transforming growth factor-beta 1 in ligamentum flavum of lumbar spinal stenosis and disc herniation. Spine (Phila Pa 1976). 2001:26(21):E492-5

18. Sairyo K, Biyani A, Goel V, Leaman D, Booth R Jr, Thomas J, et al. Pathomechanism of ligamentum flavum hypertrophy: a multidisciplinary investigation based on clinical, biomechanical, histologic, and biologic assessments. Spine (Phila Pa 1976). 2005:30(23):2649-56

19. Taher F, Essig D, Lebl DR, Hughes AP, Sama AA, Cammisa FP, et al. Lumbar degenerative disc disease: current and future concepts of diagnosis and management. Adv Orthop. 2012;2012:970752

20. Valesin Filho ES, Ueno FH, Cabral LT, Yonezaki AM, Nicolau RJ, Rodrigues LM. Prospective analysis of pain and disability of patients operated on lumbar spinal stenosis with a minimum two-year follow-up. Coluna/Columna. 2009;8(4): 390-4. 